\title{
Dynamics and impact of the coral disease white plague: insights from a simulation model
}

\author{
Marilyn E. Brandt*, John W. McManus \\ Division of Marine Biology and Fisheries, Rosenstiel School of Marine and Atmospheric Science, University of Miami, \\ 4600 Rickenbacker Causeway, Miami, Florida 33149, USA
}

\begin{abstract}
Coral disease is playing a significant role in structuring today's coral reef communities. While monitoring programs document declines associated with coral disease, there is a lack of tools that can test hypotheses of disease incidence and control. Here, we describe a modeling tool developed to test hypotheses about the spread and impact of white plague disease in diverse coral populations distributed across heterogeneous reef landscapes. The model Simulation of Infected Corals (SICO) was based on the dynamics of white plague over the course of $6 \mathrm{yr}$ of monitoring on the forereefs of Little Cayman (Cayman Islands, British West Indies). A pattern-oriented modeling approach using a genetic algorithm was used to calibrate model parameters that describe disease introduction, transmissibility, and host susceptibility. Simulation patterns most accurately reflected patterns observed at study sites when disease was introduced at regular intervals and was transmissible within a limited area. Projecting forward in time, coral cover tended to drop precipitously until colonies were so sparse that disease transmission among colonies was rare. A sensitivity analysis of disease parameters indicated that the effect of changing disease parameters depended on the type of coral community, but that in communities dominated by susceptible species, local preventative measures were generally more effective than treatment measures in limiting disease impact.
\end{abstract}

KEY WORDS: Coral disease modeling • Coral white plague disease $\cdot$ Epizootiological modeling • Individual-based modeling · Coral disease epizootiology

Resale or republication not permitted without written consent of the publisher

\section{INTRODUCTION}

Diseases have been a significant source of mortality to reef-building coral populations in recent times (Hayes \& Goreau 1998, Aronson \& Precht 2006). Monitoring programs are able to chronicle coral reef declines related to disease (e.g. Porter \& Meier 1992, Miller et al. 2003, Croquer et al. 2005), but there is a clear lack of tools capable of investigating the repercussions of disease to the structure and resilience of coral reef communities (Work et al. 2008). This study addresses the need for such tools through the development of a novel model framework specifically tailored to investigate disease dynamics in complex coral communities.

This paper describes the development of an individual-based, spatially-explicit model using a long-term data set from the island of Little Cayman (Cayman Islands, British West Indies). The objective of developing this model was to examine the dynamics and impact of apparent white plague disease (Richardson et al. 1998) within the fore-reef communities of Little Cayman, where significant declines corresponding with high levels of disease have been recorded (Coelho \& Manfrino 2007). White plague disease affects corals throughout the Caribbean region (Sutherland et al. 2004) and has demonstrated a capacity to significantly alter the structure of coral populations in other regions (Richardson \& Voss 2005). Understanding the dynamics of this disease may be important to understanding how these and other reef communities in the Caribbean will change in the future.

Many uncertainties remain concerning the causative agent(s) (hence the qualifier 'apparent') and epizootiology of white plague incidence in corals (Ainsworth et al. 2007). It is not clear whether it is a transmissible disease or one that is caused by opportunistic infection 
due to an increase in the susceptibility of the coral (Bythell et al. 2004). White plague can also be considered a type of disturbance that affects some coral species more than others (Sutherland et al. 2004). Recruitment, growth, and mortality rates of individual species influence how their populations respond to disturbances (Hughes \& Tanner 2000), and they can vary within species as well as by habitat (Edmunds \& Elahi 2007, Vermeij et al. 2007). The process of model development and implementation can sometimes provide insight into the etiology and epidemiology of a disease not otherwise possible with observation alone. This is because a model environment allows the investigator to integrate information from many sources on disease and host dynamics and examine it within a single framework. Classical models of disease, however, often treat host populations as one unit (Anderson \& May 1979). In order to understand community-level impacts from disturbances, individual-based models have been applied that are able to combine specieslevel variability and spatial patterns of colonies (e.g. Maguire \& Porter 1977, Langmead \& Sheppard 2004, Sleeman et al. 2005, Wakeford et al. 2008). Therefore, an individual-based modeling design that was able to represent the complex fore-reef coral communities of Little Cayman was used here to address questions of white plague dynamics and impact within them.

A significant benefit of developing model frameworks for disease systems is the ability to test various scenarios of prevention or control. Because of the lack of understanding about the etiology of many coral diseases, responses to outbreaks have typically focused on observation and not necessarily on intervention (Raymundo et al. 2008). As our understanding of disease transmission and coral susceptibility increases, strategies of intervention may be developed that are able to limit the effects of disease. Here we investigated hypothetical strategies of intervention by assessing the results of a sensitivity analysis of disease parameters within 4 simulated coral communities representing the Little Cayman study sites.

The model Simulation of Infected Corals (SICO) is first described following the Overview, Design concepts, and Details (ODD) protocol for detailing individual-based (or agent-based) models (Grimm et al. 2006). Following a pattern-oriented modeling approach, model performance was then assessed by comparing community-level patterns documented on Little Cayman reefs over a 6 yr monitoring period (Grimm et al. 2005). Similarities and differences between model outputs and field observations and a sensitivity analysis of disease parameters are then discussed in terms of parameterization concerns and potential future research priorities. Finally, results of intervention scenarios are discussed in terms of their impact within the various types of coral communities found on Little Cayman.

\section{METHODS}

Model description. State variables and scales: Coral colonies are the basic units of SICO, and each colony occupies a space on a 2-dimensional grid. Each colony contains a list of variables that can be assigned values (Table 1), ultimately allowing it to be unique and acquire its own history over the course of a simulation. These variables include those that describe a colony's species, size, and mortality. Simulated populations can be distributed such that their attributes represent those of real world populations based on population-level variables (Table 1). Every colony's 'probability of infection' variable is what determines whether it becomes diseased during a simulation. This variable is influenced by the colony's interaction with the model and with other colonies in the simulation. Disease is not explicitly represented within the model as an actual agent, but rather, disease incidence is determined by the actions of the individual colonies themselves.

Process overview and scheduling: The model uses discrete daily time steps, with various actions for each coral occurring in a specific order (Fig. 1). During a time step, colonies first execute commands for growth and mortality depending on their health status. A colony determines whether it will experience natural mortality, and if so, the amount of mortality experienced (Table 2, Natural mortality probability, Natural mortality range). The probability that a colony will experience natural mortality was defined for these simulations using the observed mean prevalence of natural mortality on colonies in permanent quadrats at Little Cayman reef sites (Table 3). Natural mortality range, which defines the actual amount of mortality experienced by simulated colonies if stochastically selected to experience natural mortality, was parameterized using the mean and maximum rates of mortality related to causes other than disease recorded on colonies in permanent quadrats at Little Cayman reef sites (Table 3). Once a simulated colony experiences natural mortality, it then calculates the amount of growth it will experience during that step depending on its species (Table 2, Growth rate range). The ranges for the growth rates used in these simulations were determined by a review of available literature (Table 4) and were species-specific when information on growth rates was available or, in rare circumstances, were based on rates for a similar species when published rates were not available (e.g. rates for Montastraea faveolata and $M$. franksi were based on those estimated for $M$. annularis). Once the amount of 
Table 1. Model variables. Each coral colony has a list of colony-level variables whose values can be assigned at initiation and which can change during a simulation uniquely for each colony. Each simulation run has a list of population-level variables that can be set at initiation and are used to assign values for colony-level variables. Population-level variables may change during a simulation based on how colony-level variables change within each colony (e.g. disease prevalence may fluctuate based on the number of colonies that are diseased at any time during a simulation). Feedbacks between colony-and population-level variables are indicated in the 2 rightmost columns. NA: not applicable

\begin{tabular}{|c|c|c|c|c|c|}
\hline \multicolumn{2}{|c|}{ Colony level } & \multirow{2}{*}{$\begin{array}{c}\text { Feedback of colony- } \\
\text { to population-level }\end{array}$} & \multicolumn{2}{|c|}{ Population level } & \multirow{2}{*}{$\begin{array}{l}\text { Feedback of population- } \\
\text { to colony-level }\end{array}$} \\
\hline Variable & Description & & Variable & Description & \\
\hline $\begin{array}{l}\text { Position } \\
(x, y)\end{array}$ & $\begin{array}{l}\text { Denotes a } \\
\text { colony's } x / y \text { position }\end{array}$ & NA & NA & NA & NA \\
\hline Species & $\begin{array}{l}\text { Denotes species } \\
\text { of the colony }\end{array}$ & $\begin{array}{l}\text { Species } \\
\text { composition } \\
\text { changes based } \\
\text { on the mortality } \\
\text { and recruitment } \\
\text { of colonies }\end{array}$ & $\begin{array}{l}\text { Species } \\
\text { composition }\end{array}$ & $\begin{array}{l}\text { Percent of } \\
\text { population } \\
\text { belonging to } \\
\text { each species }\end{array}$ & $\begin{array}{l}\text { Initial species } \\
\text { composition determines } \\
\text { the number of colonies } \\
\text { of each species }\end{array}$ \\
\hline $\begin{array}{l}\text { Probability } \\
\text { of infection }\end{array}$ & $\begin{array}{l}\text { Probability a } \\
\text { colony will } \\
\text { become diseased }\end{array}$ & NA & NA & NA & NA \\
\hline \multirow[t]{3}{*}{ State } & $\begin{array}{l}\text { Health status } \\
\text { of a colony } \\
\text { (healthy, diseased, } \\
\text { dead) }\end{array}$ & $\begin{array}{l}\text { Disease prevalence, } \\
\text { incidence rate, and } \\
\text { spatial correlation } \\
\text { change during a } \\
\text { simulation based } \\
\text { on colonies changing } \\
\text { their states }\end{array}$ & $\begin{array}{l}\text { Disease } \\
\text { prevalence }\end{array}$ & $\begin{array}{l}\text { Percent of } \\
\text { population in } \\
\text { diseased state }\end{array}$ & $\begin{array}{l}\text { Initial disease } \\
\text { prevalence determines } \\
\text { the number of colonies } \\
\text { with an initial state of } \\
\text { being diseased }\end{array}$ \\
\hline & & & $\begin{array}{l}\text { Disease } \\
\text { incidence rate }\end{array}$ & $\begin{array}{l}\text { Percent of } \\
\text { population } \\
\text { infected } \mathrm{d}^{-1}\end{array}$ & NA \\
\hline & & & $\begin{array}{l}\text { Disease spatial } \\
\text { correlation }\end{array}$ & $\begin{array}{l}\text { Degree of } \\
\text { aggregation of } \\
\text { diseased colonies }\end{array}$ & NA \\
\hline \multirow[t]{2}{*}{ Size } & $\begin{array}{l}\text { Max. diameter of } \\
\text { the colony }\end{array}$ & $\begin{array}{l}\text { Coral cover changes } \\
\text { based on the abundance } \\
\text { and sizes of colonies }\end{array}$ & Coral cover & $\begin{array}{l}\text { Total area of live } \\
\text { coral divided by } \\
\text { the total area } \\
\text { of the grid }\end{array}$ & NA \\
\hline & & $\begin{array}{l}\text { Size distribution } \\
\text { of colonies changes } \\
\text { based on the growth } \\
\text { and mortality of colonies }\end{array}$ & Size distribution & $\begin{array}{l}\text { Size distribution } \\
\text { of each species } \\
\text { defined by mean } \\
\text { and max }\end{array}$ & $\begin{array}{l}\text { Initial size distribution } \\
\text { determines the initial } \\
\text { sizes of colonies }\end{array}$ \\
\hline Mortality & $\begin{array}{l}\text { Mortality } \\
\text { experienced by } \\
\text { a colony }\end{array}$ & NA & NA & NA & NA \\
\hline
\end{tabular}

growth is determined for a colony during a simulation step, if it is infected, it then determines the amount of mortality it will experience due to disease based on a uniform distribution (Table 2, Disease mortality range). Disease mortality range was parameterized here using disease-related mortality rates recorded during repeated observations of white plague-affected colonies in Little Cayman (methods described below, results in Table 3). Specifically, the upper boundary of this parameter was defined by the maximum rate of diseaserelated mortality (tissue lost, in $\mathrm{cm} \mathrm{d}^{-1}$ ) observed in the field. During a simulation, if the disease mortality amount is less than the recovery threshold (Table 2), the colony will recover and become susceptible again. If the total amount of mortality (natural or disease initiated) is greater than its size, the colony will die and be removed from the grid.

If a colony does not die before the end of each time step, it will interact with the model and with other colonies in the simulation to determine the value of its 'probability of infection' variable (Table 1) for that time step. Based on this value, a susceptible colony may or may not become diseased by the end of the time step. All colonies' probability of infection variable is reset to 


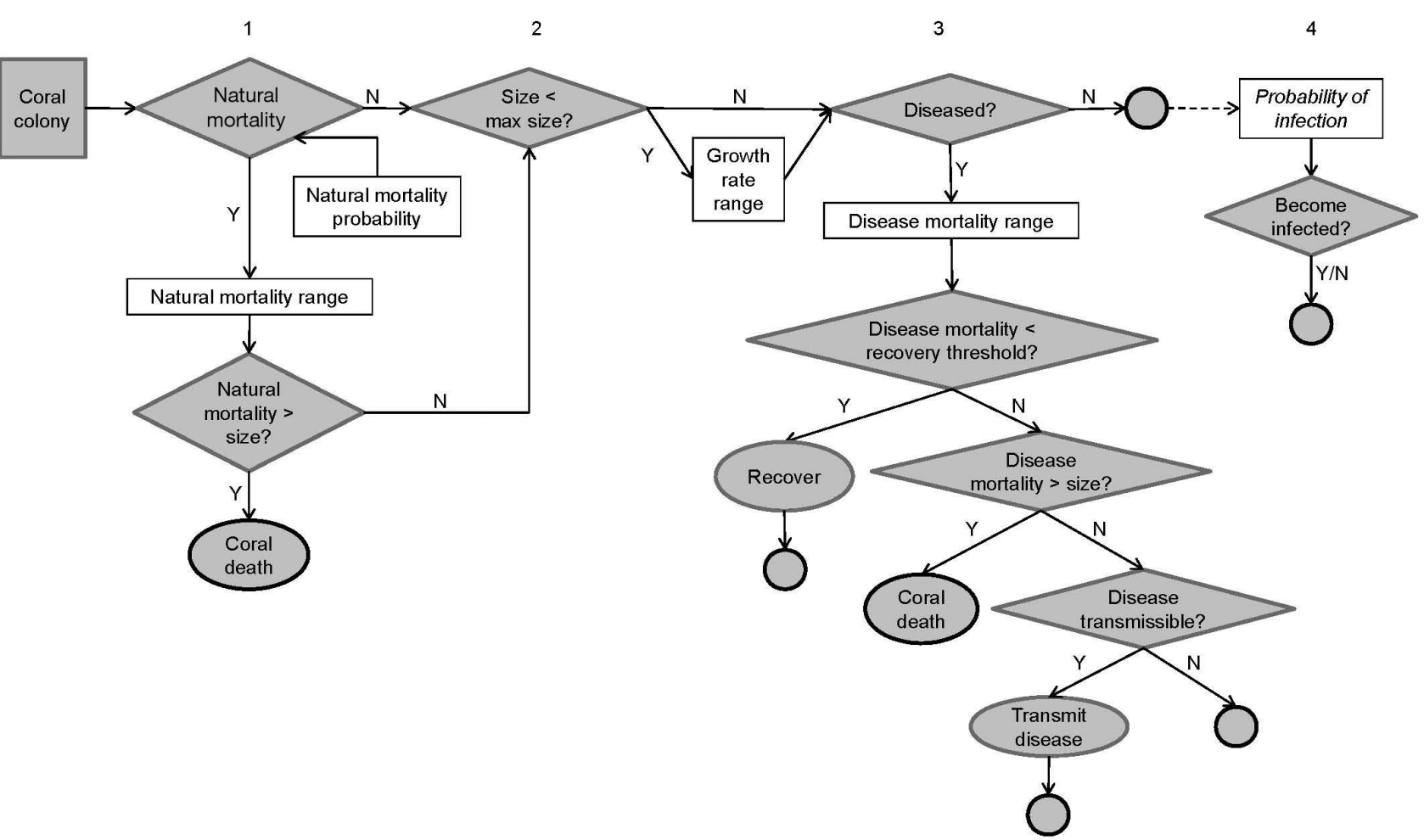

Fig. 1. Coral colony decisions during a time step (1 d). Blank circles outlined in black indicate that the colony has no more decisions or actions to complete for that time step. (1) Natural mortality probability is used to determine if the colony will experience natural mortality. If yes, it will select a random amount from a uniform range developed from empirical data. If the random amount is greater than the colony's size, it will die; if not, it will decrease the colony's size by that amount. (2) If a colony's size is less than the maximum size for its species, the colony will select a random value from a uniform range developed from literature reports of growth rates and will add that value to its size. (3) If a colony is infected, it will randomly select a disease mortality amount from a uniform range developed from empirical data. If that value is less than the recovery threshold, the colony will recover. Otherwise, if the disease mortality amount is greater than the colony's size, it will die; if not, it will decrease the colony's size by that amount. If the coral remains alive, and if disease is transmissible in the simulation, the colony will transmit disease by interacting with all other susceptible colonies. (4) At the end of the time step, all susceptible colonies become infected or remain susceptible based on the value of their probability of infection variable

0 at the beginning of a time step. All colonies go through this decision process one at a time, although the order in which colonies are selected to go through the process is randomized and does not affect the outcome of the simulation. After all colonies have performed their commands, the last action to occur in the model during a time step is recruitment, by which new corals are added to the simulation landscape.

Design concepts: Emergence: The incidence of disease during a time step is determined by interactions among colonies and between colonies and the model. Disease prevalence and changes to the population and the community are, therefore, emergent properties of the model.

Sensing: Each colony 'knows' its species, size, and location, and this influences its specific growth, mortality and its interactions with other colonies within the model.

Interaction: During calibration exercises, transmissible and non-transmissible scenarios were tested. Under transmissible scenarios, direct interaction among colonies represented the ability of disease to be transmissible within a population. In non-transmissible scenarios, direct interaction among colonies was not allowed.

Stochasticity: Growth and mortality, either due to disease or other 'natural' causes, experienced by colonies during each time step was based on random selection from uniform distributions. These distributions were bound by upper and lower limits established from empirical observations. Colonies affected by disease would recover if their selected disease mortality for a time step was less than a designated threshold. These properties reflected the inherent stochasticity of growth and mortality of corals (Baker \& Weber 1975, Sleeman et al. 2005) and the observation that diseased colonies often recover when lesion progression slows (Richardson et al. 1998, Nugues 2002).

Observation: Outputs of the model include metrics that are similar to those obtained from field studies. Field data used in this study included coral cover (areal 
Table 2. Model parameters with their descriptions and sources

\begin{tabular}{|c|c|c|}
\hline Model parameter & Description & Value / Source \\
\hline \multicolumn{3}{|l|}{ Coral parameters } \\
\hline Natural mortality probability & $\begin{array}{l}\text { Probability of a colony experiencing natural mortality during a } \\
\text { simulation day }\end{array}$ & $\begin{array}{l}0.002 \% / \\
\text { Field observations } \\
\quad \text { (Table 3) }\end{array}$ \\
\hline Natural mortality range & $\begin{array}{l}\text { Uniform distribution that defines the range for the amount of } \\
\text { tissue lost through natural mortality by a colony on a } \\
\text { simulation day }\end{array}$ & $\begin{array}{l}\text { Mean }=0.8 \mathrm{~cm} / \\
\text { Field observations } \\
\quad(\text { Table } 3)\end{array}$ \\
\hline Growth rate range & $\begin{array}{l}\text { Uniform distribution defining the range of tissue area added to } \\
\text { a colony per simulation day. Lower and upper boundaries } \\
\text { dependent on species }\end{array}$ & $\begin{array}{l}\text { Species dependent } \\
\quad \text { (Table } 4 \text { ) }\end{array}$ \\
\hline Recruitment amount & $\begin{array}{l}\text { Number that determines the number of new colonies entering } \\
\text { the simulation as juvenile corals }\end{array}$ & $\begin{array}{l}1 \mathrm{~m}^{-2} / \\
\text { References in text }\end{array}$ \\
\hline Recruitment time step & Denotes frequency of recruitment events & $\begin{array}{l}1 \text { per sim year / } \\
\text { References in text }\end{array}$ \\
\hline Area & Spatial area represented by the grid $\left(\mathrm{m}^{2}\right)$ & Input \\
\hline Alpha & $\begin{array}{l}\text { Percent of newly created colonies distributed randomly. } \\
\text { Remaining proportion distributed aggregately around } \\
\text { initial colonies }\end{array}$ & $\begin{array}{l}20 \% / \\
\text { Field observations } \\
\text { (description in text) }\end{array}$ \\
\hline \multicolumn{3}{|l|}{ Disease parameters } \\
\hline Disease mortality range & $\begin{array}{l}\text { Normal distribution defining the amount of tissue lost on a colony } \\
\text { due to disease during a simulation day. Lower boundary }=0 \text {, } \\
\text { Average = average observed in field, Maximum boundary }= \\
\text { maximum observed in field }\end{array}$ & $\begin{array}{c}\text { Mean }=5 \mathrm{~cm} \\
\text { Field observations } \\
\text { (Table 3) }\end{array}$ \\
\hline Recovery threshold & $\begin{array}{l}\text { If the simulation selects a value for disease mortality below this } \\
\text { threshold, the colony will recover }\end{array}$ & $\begin{array}{c}\text { Assumed } \\
0.001 \mathrm{~cm} \mathrm{~d}^{-1}\end{array}$ \\
\hline Seeding proportion & Percent of population selected to become infected by disease input & Unknown \\
\hline Seeding time step & $\begin{array}{l}\text { Number of simulation days during a year that disease is input into } \\
\text { the system }\end{array}$ & Unknown \\
\hline Susceptibility probability & $\begin{array}{l}\text { Inherent probability of infection of colonies when encountered by } \\
\text { an infected colony }\end{array}$ & Unknown \\
\hline$\rho$ & $\begin{array}{l}\text { Effect of distance on the force of infection between infected and } \\
\text { susceptible colonies }\end{array}$ & Unknown \\
\hline
\end{tabular}

Table 3. Mortality rates and prevalence of white plague (WP) and other mortality sources derived from field observations. Mortality rates are given as amount of tissue lost (in linear $\mathrm{cm} \mathrm{d}^{-1}$ ). Incidence proportion rates are the proportion of colonies in quadrats that became infected per day and were calculated by dividing the number of new cases of the condition observed in a quadrat by the total number of colonies in a quadrat and then by the number of monitoring days. Mortality rate for 'other' was derived from mortality observed on Agaricia agaricites, Montastraea annularis, M. faveolata, Siderastrea siderea, and S. radians. No mortality falling under the category of 'other' was found on any other species belonging to the monitored population

\begin{tabular}{|c|c|c|c|c|c|c|c|}
\hline \multirow{2}{*}{$\begin{array}{l}\text { Mortality } \\
\text { source }\end{array}$} & \multirow[b]{2}{*}{$\mathrm{N}$ (colonies) } & \multicolumn{3}{|c|}{ Mortality rate } & \multicolumn{3}{|c|}{ Incidence proportion $\left(\% \mathrm{~d}^{-1}\right)$} \\
\hline & & Mean \pm SD & Max. & Min. & $\mathrm{N}$ (quadrats) & Mean \pm SD & Max. \\
\hline WP-related & 35 & $4.4 \pm 6.8$ & 27.9 & 0.26 & 12 & $0.01 \% \pm 0.02$ & $0.07 \% \quad 0.00 \%$ \\
\hline Other ('natural') & 20 & $0.08 \pm 0.16$ & 0.73 & 0.001 & 12 & $0.002 \% \pm 0.008$ & $0.033 \% 0.000 \%$ \\
\hline
\end{tabular}

density of colonies), disease point prevalence (proportion of affected colonies at one point in time), coral community (the proportion of dominant species in the coral community), and the spatial distribution of diseased colonies.
Details: Initialization: At the start of each simulation run, coral colonies are distributed and their variables assigned such that properties of the simulated coral population (e.g. coral cover, size distribution, and community composition) reflect that intended. Interaction 
Table 4. Growth rates for individual coral species including published rates and their sources and the growth rates used in model simulations. ND = no data. Sources: 1, Bak (1976); 2, Gladfelter et al. (1978); 3, Ma (1959); 4, Present (1977; as cited by Gladfelter et al. 1978); 5, Huston (1985); 6, Hubbard \& Scaturo (1985); 7, Shinn (1966) ; 8, Aller \& Dodge (1974); 9, Baker \& Weber (1975); 10, Dustan (1975); 11, Hoffmeister \& Multer (1962); 12, Lewis et al. (1968); 13, MacIntyre \& Smith (1974); 14, Vaughn (1915); 15, Torres \& Morelock (2002)

\begin{tabular}{|c|c|c|c|c|c|}
\hline \multirow[t]{2}{*}{ Species } & \multicolumn{2}{|c|}{$\begin{array}{l}\text { Published growth } \\
\text { rate }\left(\mathrm{cm} \mathrm{yr}^{-1}\right)\end{array}$} & \multirow{2}{*}{$\begin{array}{l}\text { Max. daily } \\
\text { growth rate } \\
\quad\left(\mathrm{cm} \mathrm{d}^{-1}\right)\end{array}$} & \multirow[t]{2}{*}{ Source } & \multirow{2}{*}{$\begin{array}{c}\text { Max. daily } \\
\text { growth rate used } \\
\text { in model }\left(\mathrm{cm} \mathrm{d}^{-1}\right)\end{array}$} \\
\hline & Min. & Max. & & & \\
\hline Acropora palmata & 4.7 & 13.5 & 0.0370 & $1-4$ & 0.04 \\
\hline Agaricia agaricites & 0.08 & 2.5 & 0.0068 & 3,5 & 0.007 \\
\hline Colpophyllia natans & 0.41 & 0.93 & 0.0025 & 6,5 & 0.003 \\
\hline Diploria labrynthiformis & 0.29 & 0.45 & 0.0012 & 6 & 0.002 \\
\hline Diploria strigosa & 0.1 & 0.9 & 0.0025 & 3,5 & 0.003 \\
\hline Meandrina meandrites & 0.4 & 1.5 & 0.0041 & 3 & 0.005 \\
\hline Montastraea annularis & 0.4 & 1.2 & 0.0033 & $3,6-15$ & 0.004 \\
\hline Montastraea cavernosa & 0.2 & 0.68 & 0.0019 & 5,6 & 0.002 \\
\hline Montastraea faveolata & ND & ND & ND & ND & 0.002 \\
\hline Montastraea franksi & ND & ND & ND & ND & 0.002 \\
\hline Mycetophyllia spp. & 0.95 & 1.3 & 0.0036 & 3 & 0.004 \\
\hline Porites astreoides & 0.19 & 0.78 & 0.0021 & $2,3,5,6,15$ & 0.003 \\
\hline Porites porites & 0.36 & 0.36 & 0.0010 & 12 & 0.001 \\
\hline Siderastrea siderea & 0.14 & 0.93 & 0.0025 & $5,6,15$ & 0.003 \\
\hline
\end{tabular}

among colonies can be turned on or off, so that scenarios of transmissible disease spread and non-transmissible disease incidence can be simulated.

Input - area and coral population characteristics: The area of the 2-dimensional grid was defined as a model parameter (Table 2, area). In the simulations discussed herein, this area was set as $100 \times 100 \mathrm{~m}$, or the area of a typical reef dive site. Each grid cell was capable of containing 1 coral colony object. Coral colonies were created in batches such that the overall coral cover, species composition, and associated size distributions of the colony population were equivalent to input values. Once colonies were created, they were distributed on the grid according to the parameter alpha (Table 2). This parameter described the spatial aggregation of colonies in simulations by defining the percent of colonies distributed randomly on the grid (Lundquist \& Botsford 2004). The remaining colonies intended for aggregation were distributed in randomly selected cells surrounding already distributed colonies (Fig. 2). The simulated spatial distributions, specifically the proportion of colonies found within different distance categories out to $5 \mathrm{~m}$ from randomly selected central colonies, were compared to those found in the field. It was determined in preliminary runs that these distributions were not significantly different when alpha was between 10 and $30 \%$. Therefore, alpha was set to $20 \%$ in simulations in order to attain a level of aggregation similar to what was found at the Little Cayman study sites. It was thus possible to represent heterogeneous properties of coral populations found in nature within the model landscape.

Preliminary sets of simulations $(n=10)$ that were parameterized using coral population characteristics from the 4 Little Cayman study sites (species compositions and average sizes given in Table 5) were run in the absence of disease but with constant recruitment and natural mortality for a simulated time period equivalent to the monitoring period. Coral cover in these simulations increased by approximately 1 to $2 \%$ each year at each site (Fig. 3). This slow expansion of coral cover in the absence of disease and other sources of major disturbance (e.g. hurricanes) is consistent with the slow increase in coral abundance found at sites recovering from disturbances (Idjadi et al. 2006).

Submodels-disease incidence: Disease was not explicitly represented within the model as individual agents. Instead, individual colonies became infected based on the value of their 'probability of infection' variable, which was altered either by the model itself (disease input) or through interactions with other corals (force of infection).

Disease introduction was a process by which to 'seed' the model with disease, and was considered the extrinsic introduction of disease into the system. The 2 model parameters that determined disease introduction were disease seeding proportion, which was the proportion of colonies randomly selected to become diseased, and disease seeding time step, which defined the frequency of this occurrence (Table 2). During the process of seeding, the model would initiate the incidence of disease at a time step by changing the probability of infection variable values of the randomly selected colonies to $100 \%$.

In scenarios where colonies were allowed to interact (representing transmissible scenarios), disease was allowed to spread among colonies based on the strength 


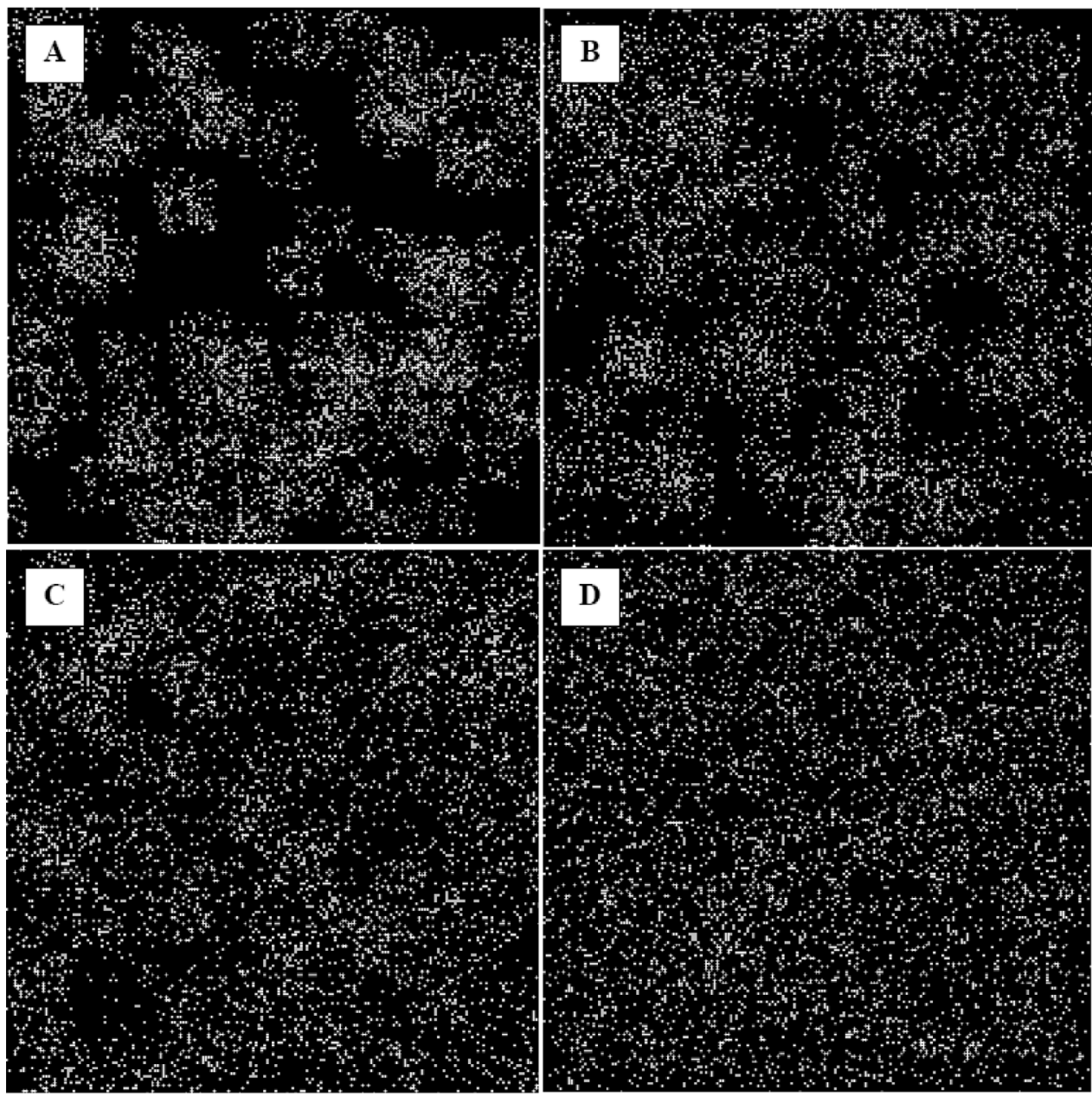

Fig. 2. Output displays of 4 simulations parameterized with identical coral densities (white cells are occupied by coral colony individuals). Each box represents different degrees of aggregation with alpha set to different levels. (A) A highly aggregated coral population where alpha $=2 \%$, (B) alpha $=10 \%,(\mathrm{C})$ alpha $=50 \%$, and (D) a completely randomly distributed coral population where alpha $=100 \%$

Table 5. Mean percent of population represented by each species (\%) and mean maximum diameter of colonies (Size, cm) recorded in transects assessed at each site in 1999. Values were used to create the initial population of coral colonies in simulations

\begin{tabular}{|c|c|c|c|c|c|c|c|c|}
\hline \multirow[t]{2}{*}{ Species } & \multicolumn{2}{|c|}{ Coral City } & \multicolumn{2}{|c|}{ Grundy's Gardens } & \multicolumn{2}{|c|}{ Jigsaw Puzzle } & \multicolumn{2}{|c|}{ Sailfin } \\
\hline & $\%$ & Size & $\%$ & Size & $\%$ & Size & $\%$ & Size \\
\hline Acropora palmata & 7 & 140.0 & 0 & - & 0 & - & 0 & - \\
\hline Agaricia agaricites & 9 & 26.7 & 19 & 33.6 & 30 & 34.5 & 15 & 38.1 \\
\hline Colpophyllia natans & 1 & 60.0 & 1 & 13.0 & 2 & 70.0 & 2 & 66.7 \\
\hline Dichocoenia stokesii & 0 & - & 0 & - & 1 & 20.0 & 1 & 15.0 \\
\hline Diploria labyrinthiformis & 3 & 29.0 & 0 & - & 6 & 42.9 & 3 & 36.1 \\
\hline Diploria strigosa & 12 & 31.6 & 3 & 10.0 & 2 & 35.0 & 4 & 34.7 \\
\hline Montastraea annularis & 28 & 47.0 & 32 & 77.5 & 28 & 57.7 & 27 & 55.6 \\
\hline Montastraea cavernosa & 5 & 22.1 & 1 & 20.0 & 8 & 33.8 & 6 & 28.7 \\
\hline Montastraea faveolata & 15 & 58.3 & 29 & 140.0 & 4 & 37.6 & 8 & 73.8 \\
\hline Montastraea franksi & 4 & 59.3 & 8 & 95.0 & 3 & 90.0 & 9 & 54.7 \\
\hline Mycetophyllia spp. & 0 & - & 0 & - & 0 & - & 1 & 15.0 \\
\hline Porites astreoides & 3 & 23.8 & 1 & 30.0 & 5 & 25.8 & 5 & 21.7 \\
\hline Porites porites & 7 & 39.0 & 3 & 35.0 & 4 & 34.0 & 15 & 34.7 \\
\hline Siderastrea siderea & 6 & 28.9 & 1 & 60.0 & 8 & 40.0 & 5 & 41.2 \\
\hline
\end{tabular}




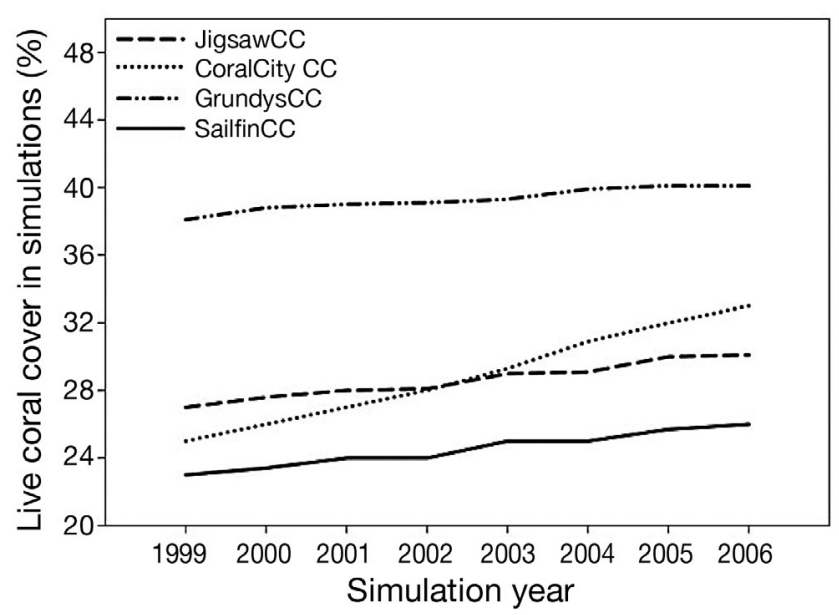

Fig. 3. Mean coral cover (CC) in simulations without disease

of the force of infection among colonies, which could be affected by distance (Shirley et al. 2003), and a competing risks model for calculating the probability of incidence of disease within each colony (Lai \& Hardy 1999).

The strength of the force of infection, $m$, from an infected colony $(j)$ to a healthy colony $(k)$ was determined by the healthy colony's susceptibility, $s$, and the distance separating the 2 colonies, $d$, which could be affected by a decay factor, $\rho$ :

$$
m_{j k}=\frac{s_{k}}{d_{j k}^{\rho}}
$$

In Eq. $1, s_{k}$ is the susceptibility of the healthy colony as defined by the disease parameter susceptibility probability (Table 2), $d_{j k}$ is the distance (grid cells) between the infected and healthy colonies, and $\rho$ is a decay factor describing the influence of distance on the spread of disease (Table 2). Therefore, distance affected the spread of disease when $\rho>0$, but not when $\rho=0$.

At the end of every simulation step, each susceptible colony had a value of its probability of infection $(p I)$ variable that was based on the forces of infection exchanged between itself $(k)$ and any infected coral $(j)$, such that:

$$
p I_{k, t}=1-\left[\prod_{j \neq k}\left(1-m_{j k, t}\right)\right]
$$

This equation is based on a competing risks model, where the individual interactions between infected corals and a healthy coral are assumed to independently affect the healthy coral's probability of infection. This probability could never exceed $100 \%$ (i.e. no coral could have a risk of disease $>100 \%$ ).

Submodels - recruitment: Recruitment, or the addition of juvenile corals to the simulation, was assumed to be open (Caley et al. 1996, Connell et al. 1997). We know of no quantitative data on recruitment rates from Little Cayman; therefore, the abundance of new corals added to the simulation was based on mean recruitment rates derived from available literature (Rogers et al. 1984, Hughes 1985, Tomascik 1991, Smith 1992). New colonies were added to the simulation at a frequency and in an amount determined by the parameters recruitment time step and recruitment amount, respectively (Table 2). The number and timing of the addition of juvenile corals were set to reflect an annual recruitment event at the start of each simulation year based on observations of Caribbean coral reproduction (Szmant 1986, Hughes \& Tanner 2000). Recruitment may have been over- or underestimated depending on species and time period because these rates may not apply specifically to Little Cayman. Parameterization of the model would therefore benefit from further studies quantifying recruitment rates specific to Little Cayman.

Measuring in the field. Study site: The model outputs were compared to data collected at 4 field sites (Coral City, Grundy's Gardens, Jigsaw Puzzle, and Sailfin Reef) surrounding Little Cayman, the smallest and least populated of the 3 Cayman Islands. Approximately half of the reef area surrounding this island is protected by a system of marine parks, which limits the extraction of resources and exposure to divers (Cayman Department of Environment 2008). Surveys using the benthic methods of the Atlantic and Gulf Rapid Reef Assessment (AGRRA) program (Kramer \& Lang 2003) took place at multiple sites in 1999, 2002, and 2004 as described below. Over the course of this time period, significant changes occurred despite little storm or anthropogenic activity in the region (Coelho \& Manfrino 2007).

Model disease: The major source of mortality during the specified time period was found to be disease signs consistent with those described for white plague type II (Coelho \& Manfrino 2007). The etiologic agent of white plague was presumed to be a novel genus and species of bacterium, Aurantimonas coralicida (Denner et al. 2003). However, recent work has established that similar disease signs may not represent common etiologies (Lesser et al. 2007). Preliminary results from samples taken from white plague lesions on colonies in Little Cayman showed that microbial communities of disease lesions were significantly different from those of healthy samples, but that they are similar to microbial communities found in lesions sampled in the Florida Keys, Dry Tortugas, and Flower Garden Banks (Cook et al. 2008).

AGRRA surveys and disease monitoring: The 4 sites were distributed around the island of Little Cayman, 2 each on the leeward and windward sides, and were surveyed in June 1999, June 2002, and February 2004 
following the benthic methodology of the AGRRA program (Kramer \& Lang 2003). This includes a line-intercept method using haphazardly placed $10 \mathrm{~m}$ transects, where all colonies $>10 \mathrm{~cm}$ that were found beneath the line were assessed for species, size, and the presence of disease. Coral cover was also measured as the percent of the available hard substrate directly under the line occupied by live coral.

In addition to AGRRA surveys, 3 randomly placed, $4 \times 4 \mathrm{~m}$ permanent quadrats were installed at 3 of the sites and 1 additional site in July 2004 (site Nancy's Cup of Tea was used in place of Jigsaw Puzzle). All coral colonies $>3 \mathrm{~cm}$ in diameter within quadrats (Table 6) were repeatedly monitored for the incidence of disease or other mortality for 3 consecutive weeks. Sites were revisited and repeatedly monitored again for 3 wk in 2005 (June-July), and then for the last time in July 2006. Tissue loss rates due to mortality events, including disease, were assessed by repeatedly photographing affected colonies from the same angle on each site visit and later analyzing area of tissue loss using the image analysis software ImageJ v1.37. Results from these observations given in Table 3 were used to define the parameters natural mortality probability, natural mortality range, and disease mortality range (Table 2).

Spatial data on the distribution of disease was collected in June 2005 using randomly placed $5 \mathrm{~m}$ radius arc transects. Randomly located white plague-affected colonies served as the center of each circular transect with a $5 \mathrm{~m}$ radius, within which all other white plagueaffected colonies were recorded, and the distance to

Table 6. Colonies monitored in permanent quadrats. Three quadrats were randomly located and installed at each site. Nancy's Cup of Tea was used in place of Jigsaw Puzzle to monitor for disease and other related mortality rates because these 2 sites exhibited similar dynamics and were in close proximity, but Nancy's was easier to access repeatedly

\begin{tabular}{|lcccc|}
\hline Species & $\begin{array}{c}\text { Coral } \\
\text { City }\end{array}$ & $\begin{array}{c}\text { Grundy's } \\
\text { Gardens }\end{array}$ & $\begin{array}{c}\text { Nancy's Cup } \\
\text { of Tea }\end{array}$ & Sailfin \\
\hline Agaricia agaricites & 41 & 166 & 207 & 182 \\
Colpophyllia natans & 1 & 2 & 1 & 0 \\
Dichocoenia stokesii & 0 & 0 & 3 & 0 \\
Diploria labyrinthiformis & 3 & 0 & 2 & 4 \\
Diploria strigosa & 45 & 4 & 1 & 7 \\
Montastraea annularis & 19 & 27 & 19 & 20 \\
Montastraea cavernosa & 13 & 0 & 28 & 6 \\
Montastraea faveolata & 38 & 14 & 15 & 13 \\
Montastraea franksi & 2 & 0 & 15 & 4 \\
Mycetophyllia spp. & 2 & 2 & 6 & 8 \\
Porites astreoides & 97 & 5 & 53 & 89 \\
Porites porites & 20 & 110 & 43 & 80 \\
Siderastrea siderea & 65 & 4 & 28 & 28 \\
& & & & \\
\hline
\end{tabular}

the center colony was measured. To determine a disease distribution that could be compared with model outputs, the mean proportion of diseased colonies found within each distance category, normalized for area, was calculated. Spatial distributions of disease recorded in simulations and in the field were statistically compared using a chi-squared goodness of fit test (Sokal \& Rohlf 2001).

Disease parameter estimation. To estimate disease parameters for which there was no empirical basis (value/source 'unknown' in Table 2), we used a genetic algorithm provided by the Java Genetic Algorithms Package (JGAP, http://jgap.sf.net). Genetic algorithms are appropriate for calibrating individualbased models (Marzloff et al. 2009). Following these methods, the set of 4 disease parameters to be estimated, including $\rho$, susceptibility probability, seeding time step, and seeding proportion, was considered the 'genotype.' The calibration process aimed to fit 3 population-level statistics (the 'phenotype') to corresponding observed statistics from the field data. These statistics included (1) mean coral cover change: mean difference in coral cover between 1999 and 2004 observations; (2) mean disease prevalence: mean proportion of colonies affected by disease in the summer of 2002; and (3) Montastraea community index: the ratio of all Montastraea colonies to all other colonies in the simulation.

All simulations were initialized based on coral population data from 1999 from Sailfin reef, and were run for a time period equivalent to the monitoring period in the field: $5 \mathrm{yr}$, or 1825 simulation 'steps,' with each step equivalent to $1 \mathrm{~d}$. The first generation of simulation runs included 200 genotypes of the disease parameters drawn randomly from uniform ranges defined for these parameters in Table 7. Following Marzloff et al. (2009), the overall fitness of a genotype, $F$, was calculated at the end of each simulation run with respect to the subfitness, $f_{i}$, of each statistic as:

$$
F=\frac{\operatorname{mean}\left(f_{i}\right)+\min \left(f_{i}\right)}{2}
$$

The sub-fitness of each statistic was based on (1) whether the simulated statistics fell within valid intervals defined by the mean and standard deviation of field observations, and (2) how close each statistic was to the target statistic, such that:

$$
f_{i}=a+b
$$

where $a=0.5$ if $s_{i} \in I_{i}$ (where $I_{i}$ is the 
Table 7. Ranges of values for disease parameters used in calibration

\begin{tabular}{|lc|}
\hline Disease parameter & Value/range \\
\hline Variable & \\
$\rho$ & $0-7$ \\
Susceptibility probability $(\%)$ & $0-10$ \\
Seeding time step & Daily, Monthly, \\
Seeding proportion $(\%)$ & Yearly \\
Constant & $0-10$ \\
Recovery threshold $(\mathrm{cm})$ & \\
$\begin{array}{l}\text { Disease mortality range } \\
\text { (average, cm) }\end{array}$ & 0.001 \\
& 5.0 \\
\hline
\end{tabular}

interval of acceptance) or $a=0$ if $s_{i} \notin I_{i}$, and $b=0.5-c_{\text {, }}$ with

$$
C=\left|\frac{\left(s_{i}-s_{o i}\right)}{S_{o i}}\right|
$$

According to their fitness, only the best 'adapted' genotypes would survive to reproduce and be the basis for new generations of genotypes. For each of the 3 statistics, the best genotypes were then used to define distributions from which to draw 100 new genotypes for the next generation. The genetic algorithm was stopped once the parameter estimation converged on an optimal genotype. The possible long-term impact of white plague on percent live coral cover was then investigated for each site by running 500 replicate $100 \mathrm{yr}$ simulations using the best-fitting parameter values.

Sensitivity analysis. We tested the sensitivity of disease parameters by varying the values of each of these parameters $50 \%$ above and below either the assumed value for Disease mortality range and Recovery threshold or that estimated through calibration for all other disease parameters (Table 2). We used coral parameter settings for each of the 4 sites, and ran simulations for a 6 yr time period. Ten replicate simulations were performed for each parameter set, and the average change in simulation coral cover was used as a measure of sensitivity. A multiple linear regression analysis was used to determine relationships between parameter values and the change in coral cover (Neter et al. 1996). The effect size was measured as the ratio between the fractional change in the response (change in coral cover) and the fractional change in the parameter being varied, or the derivative of the log response with respect to log parameter. Based on this, a sensitivity index was calculated by multiplying the linear regression coefficient for each parameter by the default (estimated) parameter value and dividing it by the change in coral cover at the default parameter value (Law 2007).

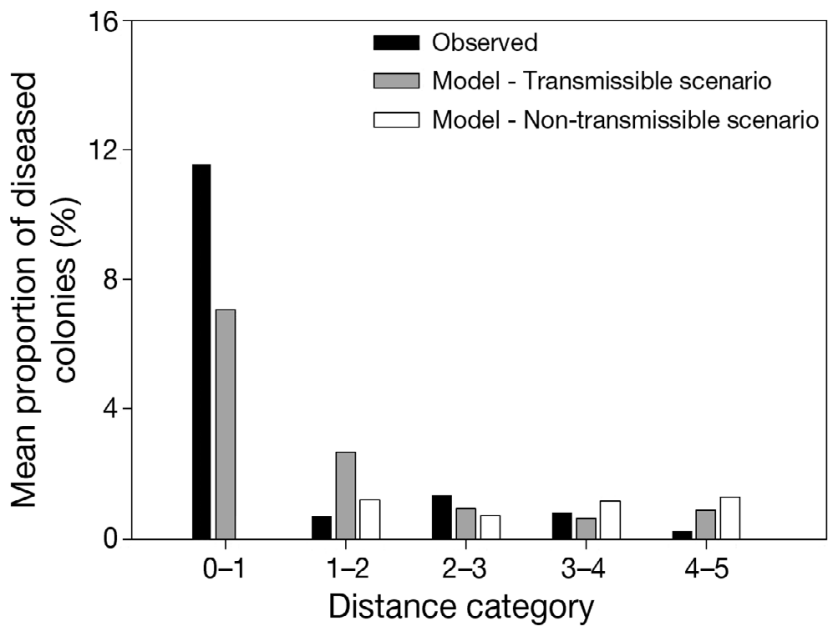

Fig. 4. Comparison between the observed distribution of diseased coral colonies and distributions of diseased colonies within simulations where disease was and was not transmissible among colonies

\section{RESULTS}

\section{Disease parameter estimation}

Accurate measures of the spatial distribution of disease were only achieved when disease was allowed to be transmissible among colonies (Fig. 4). Disease parameter optimization occurred after approximately 110 generations where a stable maximum fitness of 0.95 was achieved (Fig. 5). Best-fitting parameters included $\rho=3$, seeding time step equivalent to yearly $(=365)$ disease introduction events, disease seeding proportion $=1 \%$, and colony susceptibility probability $=1 \%$. These parameter settings were applied to simulations initialized with values from the 3 other Cayman sites. Accurate patterns of coral cover change (Fig. 6A), as

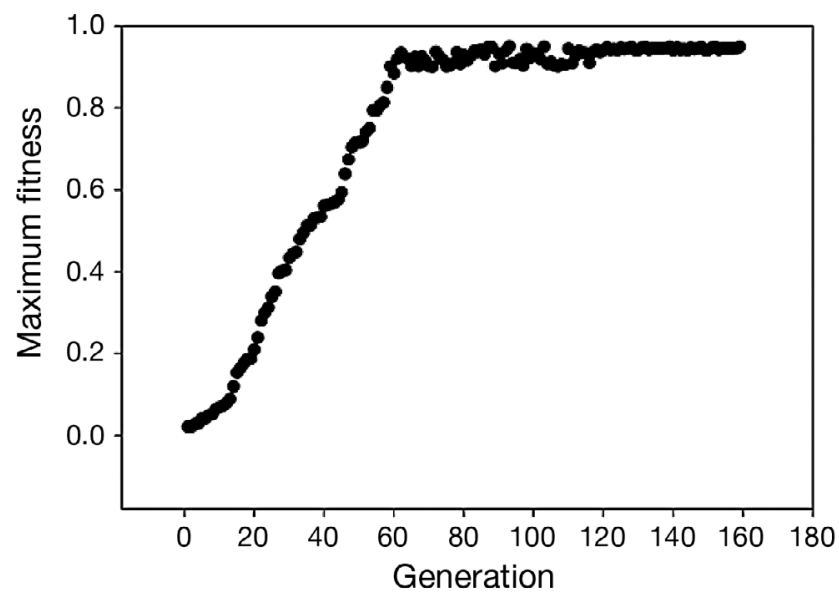

Fig. 5. Maximum fitness of simulation outputs in successively evolved generations of parameter values. Stable maximum fitness was achieved after 110 generations 

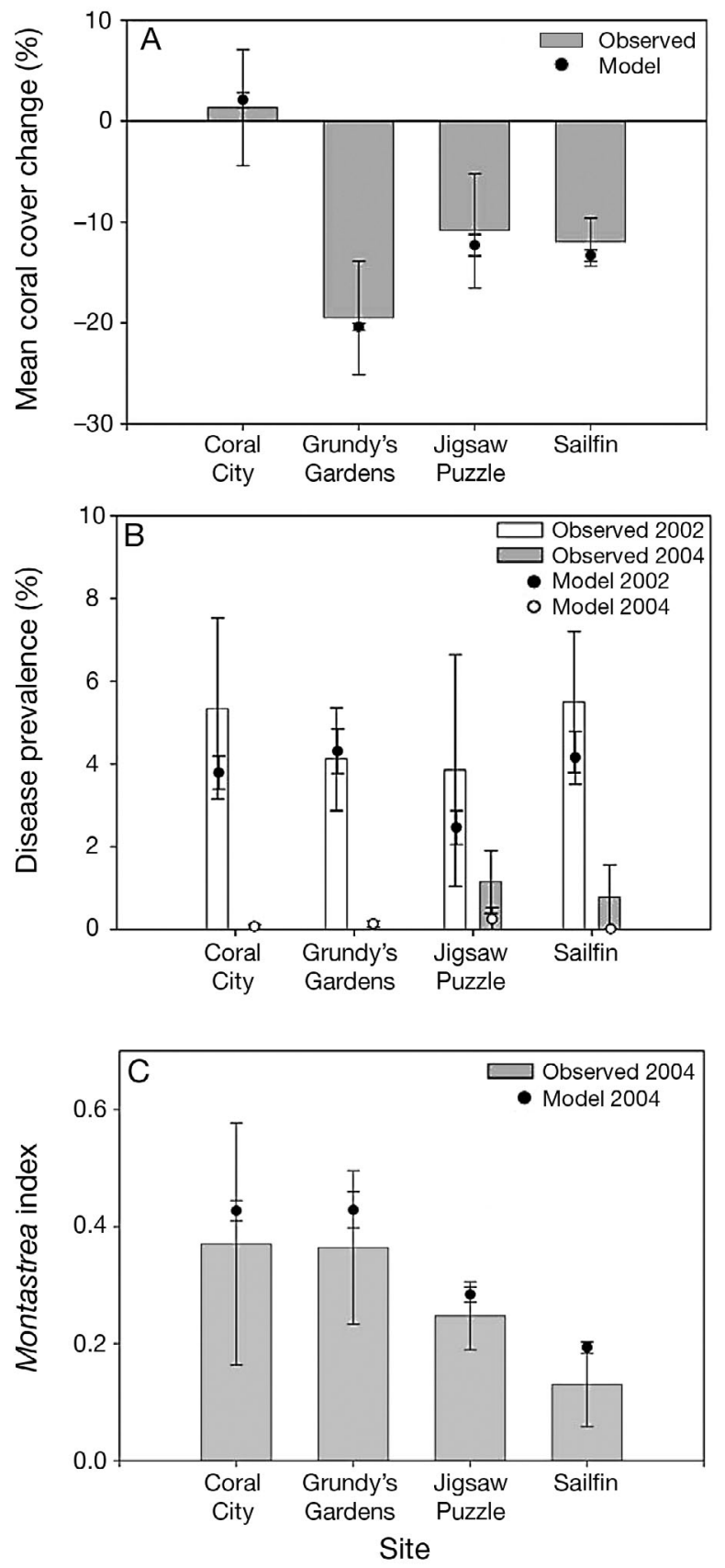

Fig. 6. Comparison between results of field observations and accurate model simulations $( \pm 95 \% \mathrm{CI})$, including (A) coral cover change over the $6 \mathrm{yr}$ monitoring period, (B) disease prevalence as measured in 2002 and 2004, and (C) the ratio of colonies of the Montastraea species complex to all other colonies

well as disease prevalence (Fig. 6B), and change in the abundance of corals of the reef-building Montastraea annularis species complex (Fig. 6C) were achieved for each of the 3 sites using the settings produced from the parameter optimization. Projections made using these parameter settings indicated that the 3 sites most affected by disease rapidly reached a state where coral cover no longer changed significantly on a yearly basis (Fig. 7).

\section{Results in response to varying parameters}

Changes in coral cover due to disease were significantly affected by changes in several disease parameters, although it depended on site (Table 8). Based on the calculated sensitivity index, changes in coral cover due to disease were largely affected by changes in $\rho$, mortality rate cap, and susceptibility at sites dominated by susceptible species (i.e. Sailfin Reef, Grundy's Gardens, and Jigsaw Puzzle). Coral cover at Coral City, where a non-susceptible species was dominant, was less sensitive to changes in disease parameters overall, but $\rho$ was also the most sensitive parameter for this site. Model results were less sensitive to seeding time step, disease seeding proportion, and recovery rate.

\section{DISCUSSION}

\section{Implications of disease parameter estimation}

Simulations in which disease distribution displayed a spatially clumped distribution similar to that observed in the field were those in which disease was transmissible among colonies. A clumped distribution in nature can indicate contagious spread of disease (Diggle 1983). However, genetic similarity associated with proximity or micro-habitat variability could create clumps of highly susceptible colonies, leading to a clumped distribution of diseased colonies. This might occur if the incidence of disease was based on a genetically-linked susceptibility factor and the genetic distribution of colonies was clumped. To our knowledge, no genotyping of colonies has yet been accomplished in Little Cayman at the scale that would allow testing of this hypothesis. This represents a further area of research for which results could easily be incorporated into the individual-based design of the model.

In simulations that most closely reflected observed data, disease was transmissible but transmission was limited to the immediate area of the colony. Longdistance transmission mechanisms (such as by water flow) may therefore be unlikely to be major factors in the spread of this specific disease. Instead, these results suggest that more likely scenarios are those that include direct tissue-to-tissue contact, or transmission through a vector that is limited in range. The vast majority of coral colonies in Cayman do not come into direct tissue contact with each other (M. E. Brandt pers. 


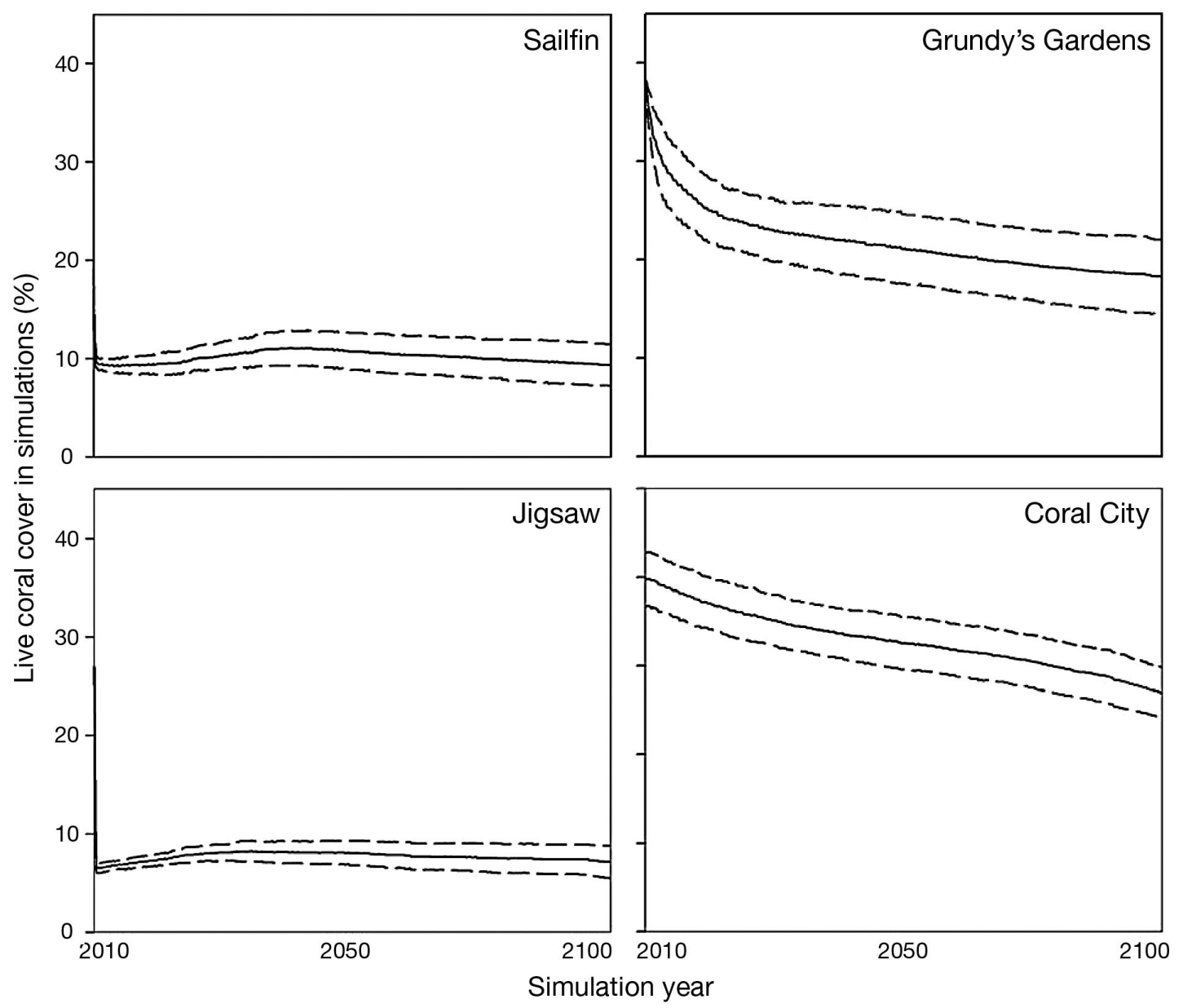

Fig. 7. $100 \mathrm{yr}$ simulations parameterized with settings resulting from parameter calibration. Solid line indicates mean percent live coral cover in simulations; dashed lines indicate \pm SD

obs.), making the first case less likely. Short-range transmission via water flow where the causative agents have a limited viability in the water would be supported by these results. Transmission by contact with algae or through a mobile predator would also constitute vectors of limited range. Other work on coral disease transmission indicates that these latter scenarios are potentially important. For instance, Nugues et al. (2004) demonstrated that algal contact with coral tissue could initiate white plague-like signs in susceptible colonies and that algae potentially act as reservoirs for pathogen populations. Other studies have found that coral pathogens can also be transmitted between corals via coral predators that come into direct contact with diseased tissue (Sussman et al. 2003, Aeby \& Santavy 2006). These results support these hypotheses, but clearly there continues to be a great need for further investigation into the transmissibility of disease in corals.

Disease propagation among colonies was required to produce accurate scenarios, but these were secondary to the required multiple disease introductions into the sys- tem. A process following this pattern has been discovered in other coral host-pathogen systems, including Aspergillosis in sea fans (Jolles et al. 2002) and bacterial bleaching of Oculina patagonica in the Mediterranean Sea (Sussman et al. 2003). In both examples, a re-introduction of the disease pathogen was required to sustain disease in the population, either through terrestrial runoff (Aspergillosis) or through the promotion of virulence factors with the return of summer temperatures (bacterial bleaching). Metapopulation dynamics can also govern the spread of disease, with one or more populations acting as sources for new disease in other distant but connected populations (Grenfell \& Harwood 1997). Metapopulation dynamics govern other ecological processes on reefs (Van Woesik 2000); therefore, it would not be surprising if this were the case for coral disease. Whether or not the disease is local or derived through connectivity with other populations, this research suggests that persistence of white plague within the coral communities of Little Cayman is dependent on a periodic reintroduction of disease into the system. 
Table 8. Results of the sensitivity analysis of disease parameters. Multiple linear regressions were performed to examine the effect on coral cover of varying each of the 6 disease parameters for each study site. A corresponding sensitivity index was calculated to measure the effect size

\begin{tabular}{|c|c|c|c|c|c|}
\hline Variable parameter & Site & Parameter estimate & SE & $\mathrm{p}$ & Sensitivity index \\
\hline Susceptibility probability & $\begin{array}{l}\text { Sailfin } \\
\text { Grundy's Gardens } \\
\text { Coral City } \\
\text { Jigsaw Puzzle }\end{array}$ & $\begin{array}{r}-4.46883 \\
-10.23233 \\
0.35500 \\
-11.44572\end{array}$ & $\begin{array}{l}0.40151 \\
0.81221 \\
0.70962 \\
1.06749\end{array}$ & $\begin{array}{r}<0.0001 \\
<0.0001 \\
0.6187 \\
<0.0001\end{array}$ & $\begin{array}{l}0.41 \\
1.14 \\
0.04 \\
0.55\end{array}$ \\
\hline Disease seeding proportion & $\begin{array}{l}\text { Sailfin } \\
\text { Grundy's Gardens } \\
\text { Coral City } \\
\text { Jigsaw Puzzle }\end{array}$ & $\begin{array}{l}-1.32553 \\
-3.16967 \\
-0.19539 \\
-1.72638\end{array}$ & $\begin{array}{l}0.40151 \\
1.87818 \\
0.64022 \\
0.96333\end{array}$ & $\begin{array}{l}0.0014 \\
0.0959 \\
0.7613 \\
0.0786\end{array}$ & $\begin{array}{r}0.15 \\
0.40 \\
-0.02 \\
0.12\end{array}$ \\
\hline Disease seeding time step & $\begin{array}{l}\text { Sailfin } \\
\text { Grundy's Gardens } \\
\text { Coral City } \\
\text { Jigsaw Puzzle }\end{array}$ & $\begin{array}{l}0.00012172 \\
0.00007208 \\
0.00003258 \\
0.00003725\end{array}$ & $\begin{array}{l}0.00004434 \\
0.00004573 \\
0.00003677 \\
0.00005530\end{array}$ & $\begin{array}{l}0.0075 \\
0.1194 \\
0.3792 \\
0.5034\end{array}$ & $\begin{array}{r}-0.40 \\
-0.24 \\
0.15 \\
-0.11\end{array}$ \\
\hline$\rho$ & $\begin{array}{l}\text { Sailfin } \\
\text { Grundy's Gardens } \\
\text { Coral City } \\
\text { Jigsaw Puzzle }\end{array}$ & $\begin{array}{l}0.05740 \\
0.11000 \\
0.00824 \\
0.10500\end{array}$ & $\begin{array}{l}0.00613 \\
0.01040 \\
0.00320 \\
0.01100\end{array}$ & $\begin{array}{r}<0.0001 \\
<0.0001 \\
0.0125 \\
<0.0001\end{array}$ & $\begin{array}{r}-1.44 \\
-4.71 \\
0.31 \\
-1.50\end{array}$ \\
\hline Mortality rate cap & $\begin{array}{l}\text { Sailfin } \\
\text { Grundy's Gardens } \\
\text { Coral City } \\
\text { Jigsaw Puzzle }\end{array}$ & $\begin{array}{l}0.03355 \\
0.02527 \\
0.00218 \\
0.02255\end{array}$ & $\begin{array}{l}0.00638 \\
0.01082 \\
0.00369 \\
0.00555\end{array}$ & $\begin{array}{r}<0.0001 \\
0.0223 \\
0.5566 \\
0.0002\end{array}$ & $\begin{array}{r}-1.28 \\
-18.05 \\
0.12 \\
-0.75\end{array}$ \\
\hline Recovery rate & $\begin{array}{l}\text { Sailfin } \\
\text { Grundy's Gardens } \\
\text { Coral City } \\
\text { Jigsaw Puzzle }\end{array}$ & $\begin{array}{r}1.45455 \\
15.45455 \\
-9.09091 \\
15.45455\end{array}$ & $\begin{array}{l}31.91091 \\
54.07890 \\
18.44970 \\
27.75074\end{array}$ & $\begin{array}{l}0.9638 \\
0.7759 \\
0.6240 \\
0.5799\end{array}$ & $\begin{array}{l}-0.01 \\
-0.22 \\
-0.11 \\
-0.11\end{array}$ \\
\hline
\end{tabular}

\section{Using models to investigate disease dynamics and impact}

For sites where susceptible species dominated the community, model outcomes were most sensitive to the disease parameters describing the extent of transmission among colonies and the susceptibility of colonies, 2 promising and important areas of research (Weil et al. 2006). A colony's susceptibility to disease can be negatively influenced by its exposure to stress, either acute or chronic (Borger 2005). Limiting coral stress factors, such as sedimentation (Fabricius 2005), exposure to injury (Henry \& Hart 2005), nutrients (Kuntz et al. 2005), and thermal anomalies (Bruno et al. 2007), may be effective at increasing colony resistance to infection. However, the capability to limit transmission is dependent on the mode of transmission, and this has not yet been definitively identified for white plague. Macroalgae are a reservoir and potential vector for the white plague type II pathogen (Nugues et al. 2004). Decreased incidence rates could potentially be achieved by reducing macroalgal abundance in the system, for example by limiting nutrient inputs or increasing herbivory by promoting herbivore populations. In some cases, increased resistance or limited transmission may occur naturally in a system through adaptation or through the removal of susceptible individuals resulting in naturally resistant populations. This natural acquisition of resistance or a declining susceptible population may be responsible for the recent inability to induce bacterial bleaching in Oculina patagonica colonies (Reshef et al. 2006, Rosenberg et al. 2007), or to infect Florida Keys colonies with Aurantimonas coralicida (Richardson \& Aronson 2002).

The parameter describing disease progression also significantly affected model outcomes at sites dominated by susceptible species, most conspicuously at Grundy's Gardens, which is dominated by large colonies of Montastraea spp. Disease mortality rates are often the defining characteristic of many coral diseases, including white plague disease (reviewed by Sutherland et al. 2004), but these rates are significantly influenced by physical factors such as light, temperature, and nutrients in other disease systems (Kuta \& Richardson 2002, Boyett et al. 2007). Halting a disease band by physical removal of the presumed affected tissue (i.e. the black band of a black band infection) has been attempted and was successful in the case of black band disease in the Florida Keys (NOAA 2009), but results for similar attempts on white plague infections in Little Cayman were variable (V. Coelho unpubl. data). In terms of practicality, this strategy may represent the most tangible of intervention strategies, but 
these results suggest that it has less of an effect than increasing disease resistance or decreasing transmission. However, a greater understanding of what influences disease progression rates is needed in order to better investigate this important parameter.

The model was much less sensitive to the timing and amount of disease introduction into the simulation environment. The paucity of information on pathogen sources makes understanding white plague introduction into a system unfeasible at the present time. If a source, such as terrestrial runoff, is identified in the future, this might represent a target for disease control and prevention measures.

\section{Disease dynamics and impact within variable coral communities}

Based on the assumptions of the model, the impact of white plague disease on the coral communities of Little Cayman was significant. A large percentage of the simulated coral cover was lost in all cases, except at Coral City, where the presence of a non-susceptible species, Acropora palmata, compensated for the loss of colonies of other susceptible species. A. palmata has historically been sensitive to the effects of disease, specifically white band disease, which is described by a similar set of signs as white plague, and may indeed represent the same disease (Bythell et al. 2004). However, white band was not observed to affect $A$. palmata in Little Cayman during this study. Regardless, these results suggest that disease will continue to play a significant role in structuring the fore-reef coral communities of Little Cayman unless actions occur to stem its current incidence rates.

Exploring the possibility of species-dependent susceptibility was beyond the scope of this study but should be explored in future modeling attempts, particularly in light of the observation that the Montastraea annularis species complex seems to be a dominant host of white plague (reviewed by Sutherland et al. 2004). Many factors may contribute to differential species susceptibility. For example, bacterial communities found within the mucus layer of corals can play a role in the resistance of disease (Ritchie 2006) and are known to differ among species (Ritchie \& Smith 1996, Klaus et al. 2005). Other attributes of corals important to disease resistance include mechanical and chemical defenses that vary by species and affect competitive hierarchies (Lang 1973, Nugues \& Bak 2006). A better understanding of species-specific defenses to disease is expected from ongoing work into the means by which corals defend against pathogen invasion (Israely et al. 2001, Geffen \& Rosenberg 2005) and what are 'normal' versus 'diseased' microbial communities of corals (Frias-Lopez et al. 2002, Johnston \& Rohwer 2007).

Understanding how susceptibility varies by species is particularly important based on the observation here that many of the disease parameters that could be targets for intervention strategies were sensitive to changes, but that this depended on the type of coral community in which the disease was acting. Strategies of preventing disease incidence within the population (increasing host resistance) would be most effective at reducing disease impact at sites highly susceptible to disease because of their species composition. At sites where non-susceptible species were also dominant, strategies of treatment (limiting transmission) were most effective. Each strategy that targets one or more of the parameters controlling disease impact may take a different form, and be associated with variable levels of cost, difficulty in implementation, and political viability. These results suggest that the type and composition of coral community affected by disease should also be accounted for when considering the best course of intervention.

\section{Field data to support model development}

The methods by which data for model parameterization are collected can significantly affect model accuracy (Law 2007). Annual large-scale monitoring efforts may be data-rich sources for model development, but the variability associated with these data can be considerable and they often are not able to provide high enough resolution for estimating important vital rates, such as disease progression. Temporally-intensive monitoring of fixed stations can provide such estimates, but this requires significant effort and alone might not represent the dynamics of the whole system (Krebs 1999). The development of SICO, therefore, was dependent on a combination of data sources, including a database of repeated AGRRA surveying on Little Cayman and additional monitoring of fixed quadrats through time. The AGRRA data provided quantitative information on population-level changes that occurred through time that were useful for calibration. Fixed station monitoring provided estimates of important rates, including disease progression and mortality due to other factors. Future model parameterization would benefit from targeted field studies aimed at supporting model development.

\section{CONCLUSIONS}

To our knowledge, the SICO model is the first attempt to produce a simulation tool with which coral 
disease can be investigated that is also capable of representing the heterogeneity inherent in coral reef ecosystems. This modeling study has identified priority coral disease-research areas that may be essential to understanding disease dynamics and impact, but that have yet to be addressed. Modeling provides a perspective not possible with laboratory or field measurements alone. However, a model is only as good as the data on which it is based. Data on coral disease transmission and host susceptibility remain relatively scarce, and more quantitative studies on these factors as well as general coral demographics would increase the accuracy of model parameterization, thereby increasing its power to predict outcomes. Ultimately, this model provides a flexible framework able to incorporate new information as it becomes available and to test new hypotheses as the field of coral disease research matures. With better models, we can continue to improve our understanding of disease dynamics within and among a diversity of coral populations in order to better conserve them for the future.

Acknowledgements. This work was funded by the Environmental Protection Agency (R82802001 to the National Center for Coral Reef Research), Rosenstiel Fellowship, Central Caribbean Marine Institute Fellowship, International Society for Reef Studies/Ocean Conservancy Fellowship, Project AWARE, Khalid bin Sultan Living Oceans Foundation, Southern Cross Club, and Head O' Bay. Field work was conducted under the auspices of the Cayman Islands Marine Conservation Board permit no. MCB-300704. We thank C. Manfrino, V. Coelho, P. Hillenbrand, J. Clamp, and W. Rhian and family for their logistical support and overall encouragement. We also thank A. Yñiguez, W. Cooper, C. Christian, D. Schmitt, J. Kennedy, A. Soranno, K. Elias, the 1999 AGRRA team, the 2002 LCRC interns, and the 2005 DWAR participants for field assistance. E. Peters, M. Schmale, D. DeAngelis, P. Glynn, and B. Riegl provided helpful advice on the manuscript, and several anonymous reviewers provided valuable recommendations.

\section{LITERATURE CITED}

Aeby GS, Santavy DL (2006) Factors affecting susceptibility of the coral Montastraea faveolata to black-band disease. Mar Ecol Prog Ser 318:103-110

Ainsworth TD, Kramasky-Winter E, Loya Y, Hoegh-Guldberg O, Fine M (2007) Coral disease diagnostics: What's between a plague and a band? Appl Environ Microbiol 73:981-992

Aller RC, Dodge RE (1974) Animal-sediment relationships in a tropical lagoon, Discovery Bay. J Mar Res 32:209-232

Anderson RM, May RM (1979) Population biology of infectious diseases: Part I. Nature 280:361-367

Aronson RB, Precht WF (2006) Conservation, precaution, and Caribbean reefs. Coral Reefs 25:441-450

Bak RPM (1976) The growth of coral colonies and the importance of crustose coralline algae and burrowing sponges in relation with carbonate accumulation. Neth J Sea Res 10:285-337
Baker PA, Weber JN (1975) Coral growth rate: variation with depth. Earth Planet Sci Lett 27:57-61

Borger JL (2005) Dark spot syndrome: a scleractinian coral disease or a general stress response? Coral Reefs 24: 139-144

Boyett HV, Bourne DG, Willis BL (2007) Elevated temperature and light enhance progression and spread of black band disease on staghorn corals of the Great Barrier Reef. Mar Biol 151:1711-1720

Bruno JF, Selig ER, Casey KS, Page CA and others (2007) Thermal stress and coral cover as drivers of coral disease outbreaks. PLoS Biol 5:e124

Bythell JC, Pantos O, Richardson L (2004) White plague, white band, and other 'white' diseases. In: Rosenberg E, Loya Y (eds) Coral health and disease. Springer, New York, p 351-365

Caley MJ, Carr MH, Hixon MA, Hughes TP, Jones GP, Menge BA (1996) Recruitment and the local dynamics of open marine populations. Annu Rev Ecol Syst 27:477-500

Caymann Islands Department of Environment (2008) Rules for Cayman Islands Marine Parks, Marine Park Regulations and Conservation Laws, Cayman Islands

> Coelho VR, Manfrino C (2007) Coral community decline at a remote Caribbean island: marine no-take reserves are not enough. Aquat Conserv 17:666-685

Connell JH, Hughes TP, Wallace CC (1997) A 30-year study of coral abundance, recruitment, and disturbance at several scales in space and time. Ecol Monogr 67:461-488

Cook GM, Sikaroodi M, Gillevet PM, Rothenberger P, Peters EC, Jonas RB (2008) Bacterial communities on healthy and diseased corals: associations with rapid tissue loss (white plague). Abstract of the 11th Int Coral Reef Symp, Ft. Lauderdale, FL, July 7-11, 2008. Available at: www. nova.edu/ncri/11icrs/abstract_files/icrs2008-001212.pdf

Cróquer A, Weil E, Zubillaga AL, Pauls SM (2005) Impact of a white plague-II outbreak on a coral reef in the archipelago Los Roques National Park, Venezuela. Caribb J Sci 41: 815-823

- Denner EBM, Smith GW, Busse HJ, Schumann P and others (2003) Aurantimonas coralicida gen. nov., sp. nov., the causative agent of white plague type II on Caribbean scleractinian corals. Int J Syst Evol Microbiol 53: 1115-1122

Diggle PJ (1983) Statistical analysis of spatial point patterns. Academic Press, New York

$>$ Dustan P (1975) Growth and form in the reef-building coral Montastraea annularis. Mar Biol 33:101-107

> Edmunds PJ, Elahi R (2007) The demographics of a 15-year decline in cover of the Caribbean reef coral Montastraea annularis. Ecol Monogr 77:3-18

Fabricius KE (2005) Effects of terrestrial runoff on the ecology of corals and coral reefs: review and synthesis. Mar Pollut Bull 50:125-146

Frias-Lopez J, Zerkle AL, Bonheyo GT, Fouke BW (2002) Partitioning of bacterial communities between seawater and healthy, black band diseased, and dead coral surfaces. Appl Environ Microbiol 68:2214-2228

Geffen Y, Rosenberg E (2005) Stress-induced rapid release of antibacterials by scleractinian corals. Mar Biol 146: 931-935

Gladfelter EH, Monahan RK, Gladfelter WB (1978) Growth rates of five reef-building corals in the Northeastern Caribbean. Bull Mar Sci 28:728-734

> Grenfell B, Harwood J (1997) (Meta)population dynamics of infectious diseases. Trends Ecol Evol 12:395-399

Grimm V, Revilla E, Berger U, Jeltsch F and others (2005) Pattern-oriented modeling of agent-based complex systems: lessons from ecology. Science 310:987-991 
Grimm V, Berger U, Bastiansen F, Eliassen S and others (2006) A standard protocol for describing individual-based and agent-based models. Ecol Model 198:115-126

Hayes RL, Goreau NI (1998) The significance of emerging diseases in the tropical coral reef ecosystem. Rev Biol Trop 46:173-185

$>$ Henry LA, Hart M (2005) Regeneration from injury and resource allocation in sponges and corals - a review. Int Rev Hydrobiol 90:125-158

Hoffmeister JE, Multer HG (1962) Fossil mangrove reef of Key Biscayne, Florida. Bull Geol Soc Am 76:845-852

Hubbard DK, Scaturo D (1985) Growth rates of seven species of scleractinian corals from Cane Bay and Salt River, St. Croix, USVI. Bull Mar Sci 36:325-338

Hughes TP (1985) Life histories and population dynamics of early successional corals. Proc 5th Int Coral Reef Symp, Tahiti, 4:101-106

Hughes TP, Tanner JE (2000) Recruitment failure, life histories, and long-term decline of Caribbean corals. Ecology 81:2250-2263

Huston M (1985) Variation in coral growth rates with depth at Discovery Bay, Jamaica. Coral Reefs 4:19-25

> Idjadi J, Lee S, Bruno J, Precht W, Allen-Requa L, Edmunds P (2006) Rapid phase-shift reversal on a Jamaican coral reef. Coral Reefs 25:209-211

Israely T, Banin E, Rosenberg E (2001) Growth, differentiation and death of Vibrio shiloi in coral tissue as a function of seawater temperature. Aquat Microb Ecol 24:1-8

Johnston IS, Rohwer F (2007) Microbial landscapes on the outer tissue surfaces of the reef-building coral Porites compressa. Coral Reefs 26:375-383

Jolles AE, Sullivan P, Alker AP, Harvell CD (2002) Disease transmission of aspergillosis in sea fans: inferring process from spatial pattern. Ecology 83:2373-2378

Klaus JS, Frias-Lopez J, Bonheyo GT, Heikoop JM, Fouke BW (2005) Bacterial communities inhabiting the healthy tissues of two Caribbean reef corals: interspecific and spatial variation. Coral Reefs 24:129-137

Kramer PR, Lang JC (2003) The Atlantic and Gulf Rapid Reef Assessment (AGRRA) protocols: former version 2.2. Atoll Res Bull 496:611-624

Krebs CJ (1999) Ecological methodology. Benjamin/Cummings, New York

Kuntz NM, Kline DI, Sandin SA, Rohwer F (2005) Pathologies and mortality rates caused by organic carbon and nutrient stressors in three Caribbean coral species. Mar Ecol Prog Ser 294:173-180

Kuta KG, Richardson LL (2002) Ecological aspects of black band disease of corals: relationships between disease incidence and environmental factors. Coral Reefs 21: 393-398

> Lai D, Hardy RJ (1999) Potential gains in life expectancy or years of potential life lost: impact of competing risks of death. Int J Epidemiol 28:894-898

Lang J (1973) Interspecific aggression by scleractinian corals. 2. Why the race is not only to the swift. Bull Mar Sci 23: 260-279

Langmead O, Sheppard C (2004) Coral reef community dynamics and disturbance: a simulation model. Ecol Model 175:271-290

Law AM (2007) Simulation modeling and analysis, McGrawHill, New York

Lesser MP, Bythell JC, Gates RD, Johnstone RW, HoeghGuldberg O (2007) Are infectious diseases really killing corals? Alternative interpretations of the experimental and ecological data. J Exp Mar Biol Ecol 346:36-44

Lewis JB, Axelson F, Goodbody I, Page C, Chislett G (1968)
Comparative growth rates of some corals in the Caribbean. Marine Science Mammal Report, McGill University, Montreal

> Lundquist CJ, Botsford LW (2004) Model projections of the fishery implications of the Allee effect in broadcast spawners. Ecol Appl 14:929-941

Ma TH (1959) Effect of water temperature on growth rate of corals. Oceanographica Sinica, World Book Co., Taipei

MacIntyre IG, Smith SV (1974) X-radiographic studies of skeletal development in coral colonies. Proc 2nd Int Coral Reef Symp, Australia, 1:227-287

Maguire LA, Porter JW (1977) A spatial model of growth and competition strategies in coral communities. Ecol Model 3:249-277

Marzloff M, Shin YJ, Tam J, Travers M, Bertrand A (2009) Trophic structure of the Peruvian marine ecosystem in 2000-2006: insights on the effects of management scenarios for the hake fishery using the IBM trophic model Osmose. J Mar Syst 75:290-304

> Miller J, Rogers C, Waara R (2003) Monitoring the coral disease, plague type II, on coral reefs in St. John, US Virgin Islands. Rev Biol Trop 51:47-55

Neter J, Kutner MH, Nachtsheim CJ, Wasserman W (1996) Applied linear statistical models. WCB McGraw-Hill, New York

NOAA (2009) Coral disease identification and information, black band management. Available at: www.coral.noaa. gov/coral_disease/black_band_management.shtml

> Nugues MM (2002) Impact of a coral disease outbreak on coral communities in St. Lucia: What and how much has been lost? Mar Ecol Prog Ser 229:61-71

> Nugues MM, Bak RPM (2006) Differential competitive abilities between Caribbean coral species and a brown alga: a year of experiments and a long-term perspective. Mar Ecol Prog Ser 315:75-86

> Nugues MM, Smith GW, van Hooidonk RJ, Seabra MI, Bak RPM (2004) Algal contact as a trigger for coral disease. Ecol Lett 7:919-923

Porter JW, Meier OW (1992) Quantification of loss and change in Floridian reef coral populations. Am Zool 32:625-640

> Reshef L, Koren O, Loya Y, Zilber-Rosenberg I, Rosenberg E (2006) The coral probiotic hypothesis. Environ Microbiol 8:2068-2073

Raymundo LJ, Couch CS, Harvell CD (2008) Coral disease handbook; guidelines for assessment, monitoring and management. Coral Reef Targeted Research and Capacity Building for Management Program, St Lucia

Richardson LL, Aronson RB (2002) Infectious diseases of reef corals. Proc 9th Int Coral Reef Symp, Bali 2: $1225-1230$

Richardson LL, Voss JD (2005) Changes in a coral population on reefs of the northern Florida Keys following a coral disease epizootic. Mar Ecol Prog Ser 297:147-156

Richardson LL, Goldberg WM, Carlton RG, Halas JC (1998) Coral disease outbreak in the Florida Keys: plague type II. Rev Biol Trop 46:187-198

> Ritchie KB (2006) Regulation of microbial populations by coral surface mucus and mucus-associated bacteria. Mar Ecol Prog Ser 322:1-14

Ritchie KB, Smith GW (1996) Physiological comparison of bacterial communities from various species of scleractinian corals. Proc 8th Int Coral Reef Symp, Panama City, $1: 521-526$

Rogers CS, Fitz HC, Gilnack M, Beets J, Hardin J (1984) Scleractinian coral recruitment patterns at Salt River submarine canyon, St. Croix, United States Virgin Islands. Coral Reefs 3:69-76 
Rosenberg E, Koren O, Reshef L, Efrony R, Zilber-Rosenberg I (2007) The role of microorganisms in coral health, disease and evolution. Nat Rev Microbiol 5:355-362

Shinn EA (1966) Coral growth rate. An environmental indicator. J Paleontol 40:233-240

Shirley MDF, Rushtown SP, Smith GC, South AB, Lurz PWW (2003) Investigating the spatial dynamics of bovine tuberculosis in badger populations: evaluating an individualbased simulation model. Ecol Model 167:139-157

Sleeman JC, Boggs GS, Radford BC, Kendrick GA (2005) Using agent-based models to aid reef restoration: enhancing coral cover and topographic complexity through the spatial arrangement of coral transplants. Restor Ecol 13:685-694

Smith SR (1992) Patterns of coral recruitment and postsettlement mortality on Bermuda's reefs: comparisons to Caribbean and Pacific reefs. Am Zool 32:663-673

Sokal RR, Rohlf FJ (2001) Biometry; the principles and practice of statistics in biological research. WH Freeman \& Company, New York

Sussman M, Loya Y, Fine M, Rosenberg E (2003) The marine fireworm Hermodice carunculata is a winter reservoir and spring-summer vector for the coral-bleaching pathogen Vibrio shiloi. Environ Microbiol 5:250-255

Sutherland KP, Porter JW, Torres C (2004) Disease and immunity in Caribbean and Indo-Pacific zooxanthellate corals. Mar Ecol Prog Ser 266:273-302

Szmant AM (1986) Reproductive ecology of Caribbean reef

Editorial responsibility: Kiho Kim,

Washington, DC, USA corals. Coral Reefs 5:43-53

Tomascik T (1991) Settlement patterns of Caribbean scleractinian corals on artificial substrata along a eutrophication gradient, Barbados, West Indies. Mar Ecol Prog Ser 77: 261-269

Torres JL, Morelock J (2002) Effect of terrigenous sediment influx on coral cover and linear extension rates of three Caribbean massive coral species. Caribb J Sci 38:222-229

$>$ Van Woesik R (2000) Modelling processes that generate and maintain coral community diversity. Biodivers Conserv 9: $1219-1233$

Vaughn TW (1915) The geologic significance of the growth rate of the Florida and Bahaman Shoal-water corals. J Wash Acad Sci 5:591-600

Vermeij MJA, Frade PR, Jacinto RIR, Debrot AO, Bak RPM (2007) Effects of reproductive mode on habitat-related differences in the population structure of eight Caribbean coral species. Mar Ecol Prog Ser 351:91-102

Wakeford M, Done TJ, Johnson CR (2008) Decadal trends in a coral community and evidence of changed disturbance regime. Coral Reefs 27:1-13

Weil E, Smith G, Gil-Agudelo DL (2006) Status and progress in coral reef disease research. Dis Aquat Org 69:1-7

Work TM, Richardson LL, Reynolds TL, Willis BL (2008) Biomedical and veterinary science can increase our understanding of coral disease. J Exp Mar Biol Ecol 362: $63-70$

Submitted: December 8, 2008; Accepted: August 28, 2009 Proofs received from author(s): October 13, 2009 